\title{
ANALISIS NON LINIER TREMOR VULKANIK GUNUNGAPI RAUNG JAWA TIMUR-INDONESIA
}

\author{
Oleh: \\ Arin Wildani ${ }^{1}$, Sukir Maryanto ${ }^{2}$, Hendra Gunawan ${ }^{3}$, Hetty Triastuty ${ }^{3}$ \\ Muhammad Hendrasto ${ }^{3}$
}

\begin{abstract}
ABSTRAK : Penelitian mengenai aktifitas tremor vulkanik gunung Raung yang terekam pada bulan Oktober 2012 telah dilakukan. Data yang digunakan pada penelitian ini yaitu data tremor vulkanik yang terekam pada tanggal 17 Oktober sampai 16 November 2012. Penelitian dimulai dengan seleksi event tremor vulkanik yang jelas. Selanjutnya dilakukan rekonstruksi diagram attraktor dari tremor vulkanik gunung Raung dengan menggunakan teorema delay embedding. Delay time untuk merekonstruksi diagram attraktor ditentukan dengan menggunakan Metode Mutual Information (MI) dan didapatkan delay time tremor vulkanik gunung Raung dalam range 0,08 s - 0,09s. Dimensi embedding ditentukan dengan menggunakan metode False Nearest Neighbour (FNN) dan didapatkan dimensi embedding tremor vulkanik gunung Raung dalam range 4-5. Dengan menggunakan delay time dan dimensi embedding yang didapatkan maka diagram attraktor dapat direkonstruksi. Dimensi fraktal dihitung dengan menggunakan metode dimensi korelasi dan didapatkan nilai dimensi fraktal tremor vulkanik gunung Raung berkisar 2,91 - 3,35. Nilai Lyapunov exponent tremor vulkanik gunung Raung didapatkan berkisar 0,016 - 0,030. Berdasarkan dimensi fraktal dan Lyapunov exponent tremor vulkanik gunungapi Raung bersifat kaotik.
\end{abstract}

Kata Kunci : Analisis non linier, gunung Raung, spektral frekuensi, tremor vulkanik.

\begin{abstract}
Volcanic tremors atRaung volcano which occurred in 2012 have been studied in order to understand it characteristics. The research was done by analyzing seismogram of volcanic tremor that was recorded on October $17^{\text {th }}-$ November $16^{\text {th }} 2012$.The volcanic tremor analysis started with the selection of volcanic tremor that recorded at Raung volcano clearly. Spectral analysis was done to determine frequency content of volcanic tremor. Base on the average periodogram method, the result of spectral analysis shown that the frequency of volcanic tremor range about $2.81 \mathrm{~Hz}-3.21 \mathrm{~Hz}$. Nonlinear analysis was done to determine the value of the fractal dimension and Lyapunov exponent of volcanic tremor by reconstruction the phase space using the delay embedding theorem. The delay time used for reconstruction was chosen after examining the first minimum of the Mutual Information (MI) of the data. In most cases it was found that a delay time has range about $0.09 \mathrm{~s}-0.10 \mathrm{~s}$. The sufficient embedding dimension was estimated using the False Nearest Neighbour (FNN) method which hasrange about of $4-5$. Base on these embedding parameter is was possible to calculate the correlation dimension of the resulting phase space, as well as the average divergence rate of nearby orbit given by the largest Lyapunov exponent. Corellation dimension value of volcanic tremor of mount Raung has range about2.91 to 3.35 and Lyapunov exponent has range about 0.016 to 0.030. Based on the value of the frequency content, the value corellation dimension and the value Lyapunov exponent which was gotten thus volcanic tremor source can be stated as stable source.
\end{abstract}

Key Words: Nonlinear analysis, raung mount, spectral frequency, volcanic tremor.

\section{PENDAHULUAN}

Gunung Raung merupakan salahsatu gunungapi aktif yang termasuk dalam deretan gunungapi Indonesia. Secara geografis puncak gunung Raung terletak pada posisi $8^{\circ} 07^{\prime}$

\footnotetext{
${ }^{1}$ Program Pasca Sarjana Jurusan Fisika, FMIPA, Universitas Brawijaya (email:arinwildani@gmail.com)

2 Jurusan Fisika, FMIPA, Universitas Brawijaya

${ }^{3}$ Pusat Vulkanologi dan Mitigasi Bencana Geologi
} 
30" LS dan $114^{\circ} 02$ ' 30" BT dengan tinggi puncaknya 3332 meter diatas permukaan laut. Secara administratif gunung Raung termasuk dalam tiga wilayah Kabupaten, yaitu Bondowoso, Banyuwangi, dan Jember Propinsi Jawa Timur. Kegiatan gunung Raung umumnya dicirikan oleh hembusan asap kawah berwarna putih tipis dengan ketinggian berkisar antara 50 hingga 75 meter dari puncak [1].

Tremor vulkanik merupakan gelombang seismik yang biasa teramati didekat gunungapi aktif [2]. Berdasarkan kenampakan bentuk gelombangnya tremor vulkanik dibagi menjadi dua yaitu tremor harmonik dengan kenampakan yang teratur dan tremor spasmodik dengan kenampakan yang tidak teratur [3]. Penelitian mengenai tremor vulkanik biasanya terkait dengan kakakteristik dan mekanisme sumbernya. Beberapa penelitian mengenai mekanisme sumber tremor vulkanik antara lain; tremor vulkanik diduga merupakan hasil resonansi gas didalam pipa konduit [4], proses non linier didalam saluran magma berbentuk silinder [5] dan diduga dihasilkan oleh aliran magma yang mempunyai dua fase fluida yaitu fase gas dan fase cair [6].

Mekanisme terjadinya tremor vulkanik belum bisa diterangkan secara jelas walaupun berasal dari gunung yang sama. Apabila suatu tremor merupakan hasil dari suatu getaran akibat aliran fluida magma tidak steady pada kantong magma yang dapat dianggap sebagai suatu sistem dinamik yang kaotik, maka analisis frekuensi tidak cukup untuk membedakan karakteristik tremor vulkanik tersebut. Untuk itu perlu dilakukan analisis non linier [5].

Analisis non linier untuk sinyal seismik yang berasal dari gunungapi merupakan cara analisis baru dan telah dilakukan oleh beberapa peneliti sebelumnya antara lain pada data tremor vulkanik gunung Sangay di Ekuador [7] dan pada data dari gunung Semeru di Indonesia [8]. Pada bulan Oktober tahun 2012 gunung Raung menunjukkan aktifitas yang berbeda dari biasanya, kawah gunung Raung terus menyemburkan asap dan mengeluarkan suara gemuruh, erupsinya berupa letupan gas yang ditandai dengan asap tebal berwarna kehitaman. Gempa tremor terus meningkat dengan amplitudo maksimum 32 milimeter yang diikuti dengan hembusan asap dari puncak yang berkisar 50-75 meter. Pada tanggal 22 Oktober 2012 pukul 22.30 WIB status gunung Raung ditingkatkan menjadi siaga. Selama ini penelitian mengenai aktifitas seismik gunung Raung belum pernah dilakukan. Oleh karena itu penelitian ini menjadi sangat penting untuk dilakukan dan bisa dijadikan sebagai studi pendahuluan mengenai aktifitas seismik gunung Raung.

Pemantauan aktifitas gunung Raung telah dilakukan oleh Pusat Vulkanologi dan Mitigasi Bencana Geologi (PVMBG) dengan menggunakan tiga stasiun seismik seperti terlihat pada Gambar 1. Satu stasiun seismik bersifat permanen dan dua lainnya bersifat temporer dengan menggunakan seismometer 1 komponen tipe L4-C.
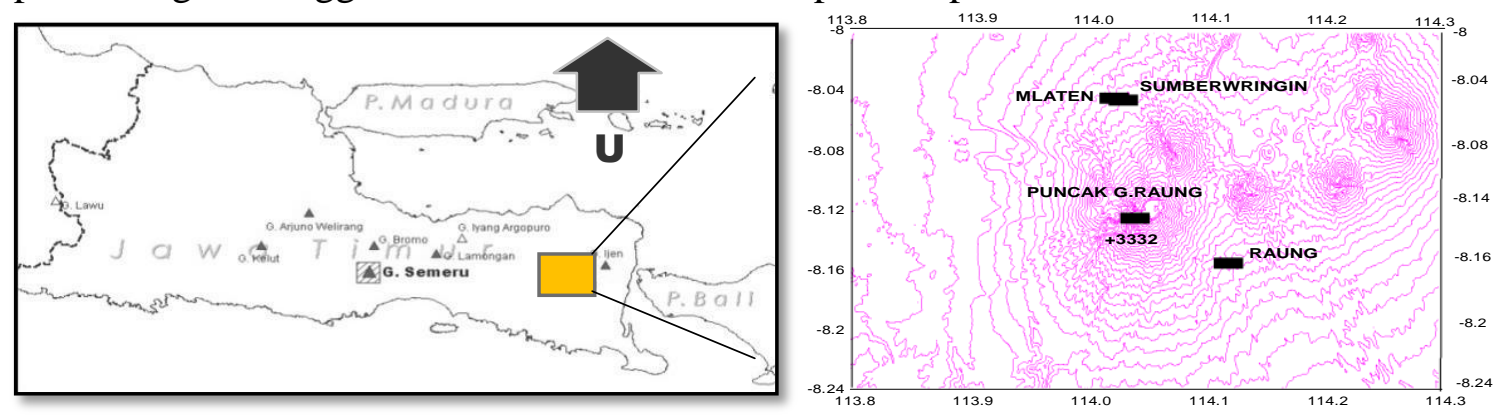

Gambar 1. Lokasi stasiun seismik gunung Raung 


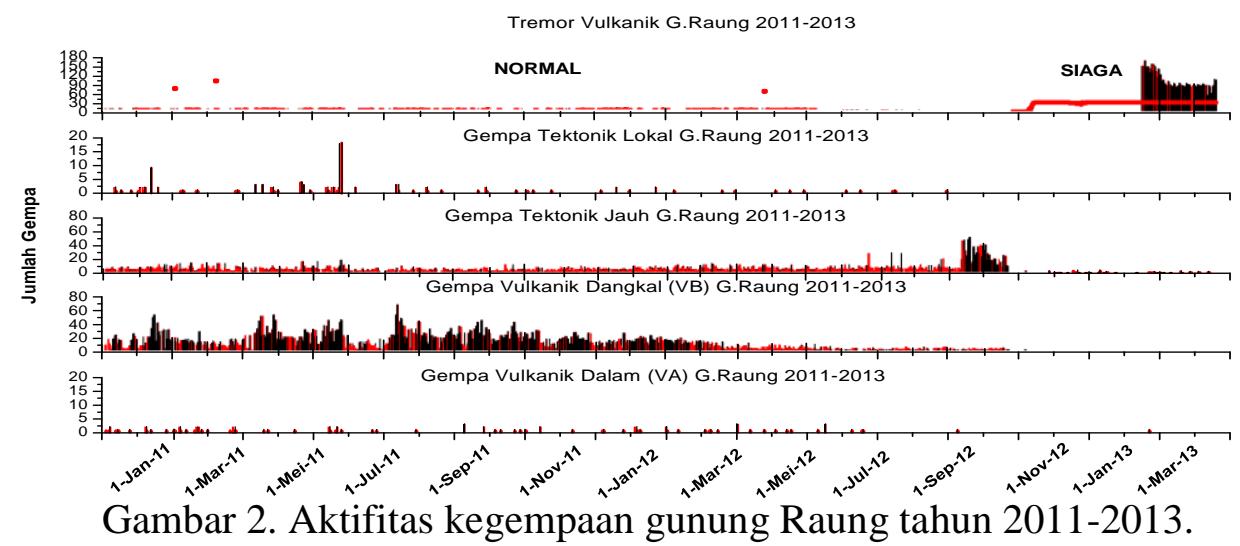

Aktfitas kegempaan gunung Raung didominasi oleh gempa vulkanik dangkal. Gambar 2 memperlihatkan grafik kegempaan gunung tahun 2011-2013. Data yang digunakan pada penelitian ini merupakan data sekunder yaitu data rekaman seismik (seismogram) gunung Raung tanggal 17 Oktober 2012 sampai 16 November 2012. Pada tanggal tersebut tremor vulkanik gunung Raung mulai terekam. Gambar 3 merupakan seismogram gempa tremor gunung Raung yang terekam tanggal 17 Oktober 2012 pukul 00.00 WIB s/d 04.00 WIB pada stasiun Raung. Berdasarkan kenampakan bentuk gelombangnya tremor vulkanik gunung Raung merupakan tremor spasmodik.
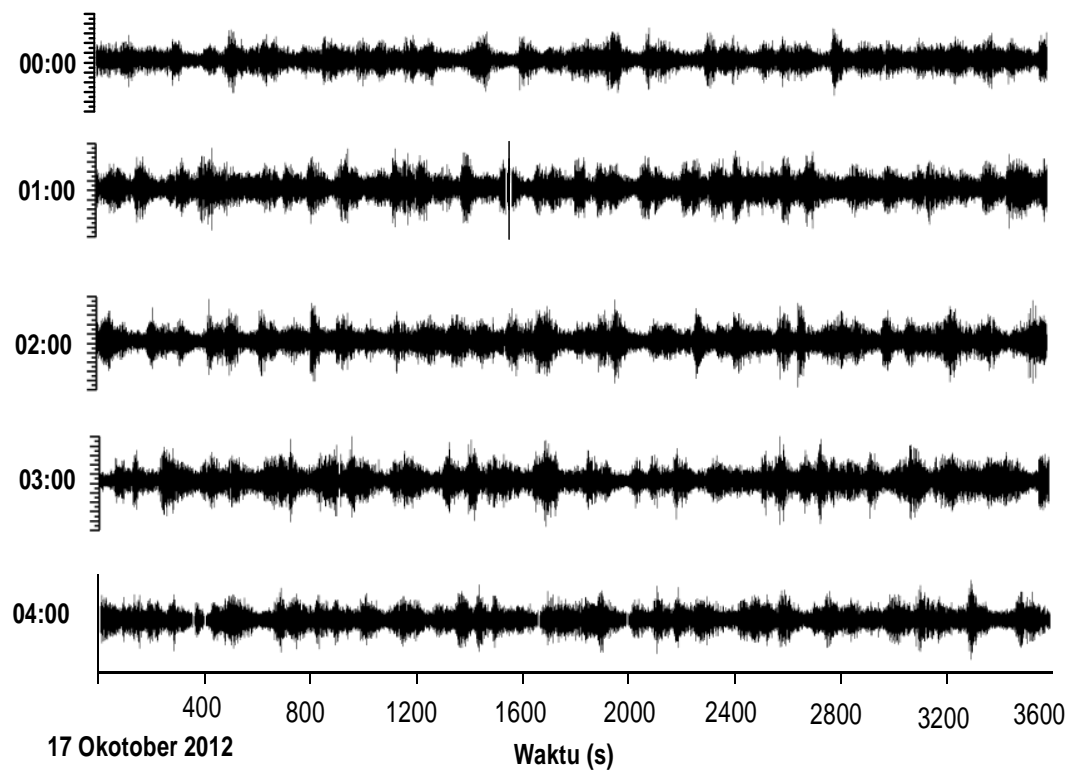

Gambar 3. Seismogram tremor vulkanik gunung Raung tangal 17 Oktober 2012 pukul 00.00 s/d 04.00 WIB terekam di stasiun Raung.

\section{REKONSTRUKSI DIAGRAM ATTRAKTOR}

Teorema Delay Embedding menyatakan bahwa vektor pada ruang yang baru, ruang embedding, dibentuk dari kumpulan data berdasarkan delay time. Teorema Delay Embedding dinyatakan pada persamaan 1 sebagai berikut;

$$
=\quad+\quad+\tau, \quad+2 \tau, \ldots,(+-1 \tau)
$$

dimana $\tau$ merupakan delay time dan $m$ merupakan dimensi embedding [9]. 


\section{SELEKSI DELAY TIME}

Delay time ditentukan dengan menggunakan metode Mutual Information (MI) dan delay time dipilih nilai minimum pertama. Mutual Information (MI) dari data runtun waktu $X_{i}(i=1,2,3, \ldots M)$ didefinisikan sebagai berikut:

MI X, Y = i j $p_{x y} i, j \log \frac{p_{x y}(i, j)}{p_{x}(i) p_{y}(j)}$

dimana $p_{x}(i)$ merupakan probability distribution dari $X_{i}$ dan $p_{y}(j)$ merupakan probability distribution dari $Y_{j}(j=\alpha, \alpha+1, \ldots, \alpha+M)$ [10]. Gambar 4 merupakan delay time tremor vulkanik gunung Raung didapatkan nilai minimum pertama pada timelag ke 9 atau 0,09 sekon (timelag dikalikan dengan sampling rate).

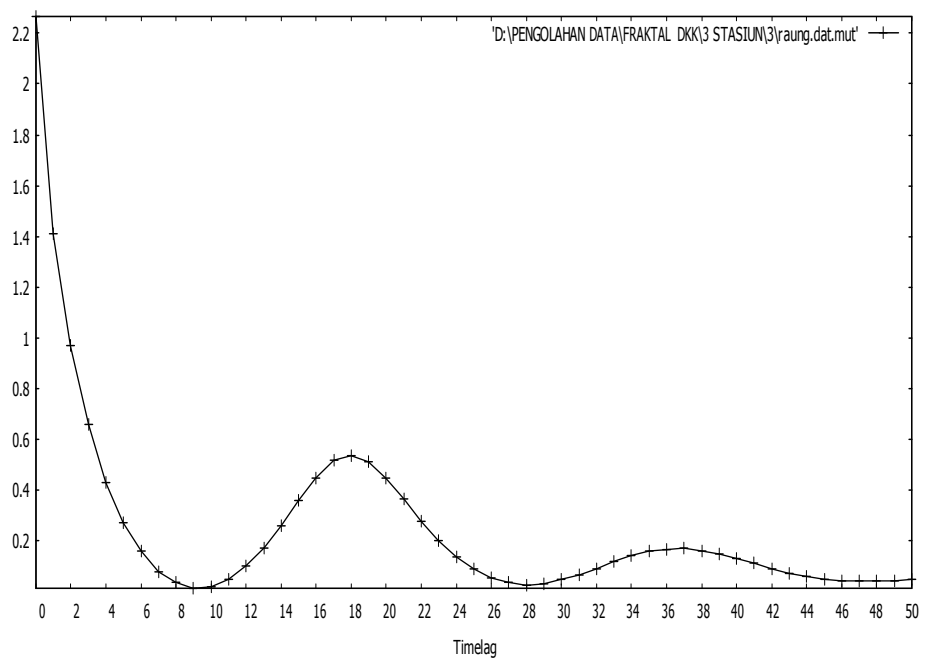

Gambar 4. Seleksi delay time dengan metode Mutual Information (MI).

\section{SELEKSI DIMENSI EMBEDDING}

Perilaku kaotik dalam diagram attraktor ditunjukkan dengan tidak adanya orbit yang tumpang tindih, oleh karena itu dimensi embedding yang digunakan untuk rekonstruksi diagram attraktor harus sesuai. Metode yang digunakan untuk menentukan dimensi embedding yang sesuai yaitu False Nearest Neighbour (FNN). FNN terjadi pada suatu kondisi dimana jarak antara titik-titik (data) pada saat dimensi tertentu, jauh melampaui tresshold pada saat titik-titik tersebut berada di dimensi lainnya. Asumsikan bahwa titik $x^{a}$ dan $x^{b}$ saling berdekatan dalam diagram attraktor. Jarak antara dua titik tersebut yaitu

- $\quad$, untuk mengetahui apakah kedua titik tersebut termasuk FNN maka dapat dilakukan dengan membandingkan jarak Euclidian kedua titik tersebut di dua dimensi embedding berturut-turut misalnya dimensi embedding $d$ dan $d+1$. Jarak Euclidian dua titik untuk dimensi embedding $m$ dan delay time $\tau$ sebagai berikut;

$$
\stackrel{2}{d}=\underset{=0}{d-1}+\tau-(+\tau)^{2}
$$

Jika dimensi berpindah dari $d$ ke $d+1$ maka koordinat yang baru menjadi $s(t+d \tau)$, sehingga jarak Euclidean dua titik dalam dimensi yang baru $d+1$ menjadi;

$$
{ }_{d+1}^{2}=\underset{d}{2}+\quad+d \tau-(+d \tau)^{2}
$$

Jarak relatif antara dua titik di dimensi $d$ dan $d+1$ sebagai berikut:

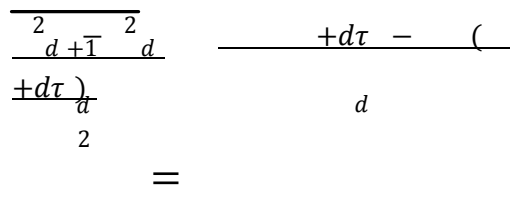


Jika perbandingan jarak pada persamaan 5 lebih besar dari $s$, dimana $s$ besarnya ditentukan, maka Nearest Neighbour dengan jumlah dimensi yang digunakan merupakan FNN. sehingga proses akan terus diiterasikan lagi dengan jumlah dimensi selanjutnya sampai nilai $\mathrm{FNN}=0$ [7].

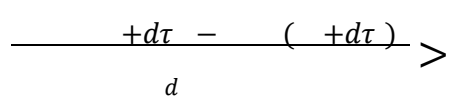

Nilai $s$ untuk sistem non linier berharga 15 [7]. Gambar 5 memperlihatkan FNN=0 Saat dimensi embedding 4, hal ini berarti dimensi embedding yang sesuai untuk rekonstruksi diagram attraktor yaitu 4 .

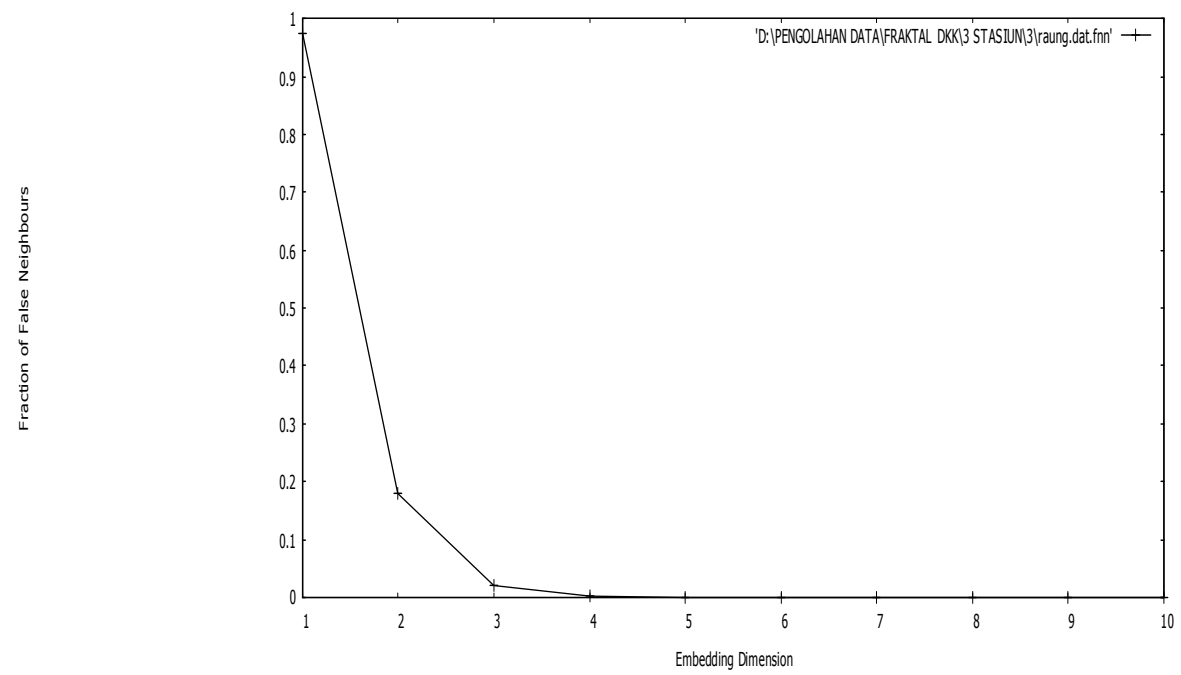

Gambar 5. Seleksi dimensi embedding dengan menggunakan metode False Nearest Neighbour (FNN).

\section{ESTIMASI DIMENSI KORELASI}

Struktur fraktal sering ditemukan pada diagram attraktor dimana harga kuantitasi fraktalnya disebut dimensi fraktal. Penentuan dimensi fraktal dapat dihitung dengan metode dimensi korelasi $(d)$ sebagai berikut;

$$
\begin{aligned}
& d=\lim _{\rightarrow 0} \frac{\ln (1)}{\ln ()} \\
& \text { dengan } \\
& =\lim _{\rightarrow 0} \frac{1}{N(N-1)} \stackrel{\substack{N-1 \\
=1}}{N}=1 \quad(-\quad-
\end{aligned}
$$

$H(s)=1$ jika $s>0$ dan $H(s)=0$ jika $s<0$. Dimensi embedding dan delay time yang digunakan yaitu dimensi embedding dan delay time yang didapatkan dari perhitungan sebelumnya [9]. Gambar 6 memperlihatkan grafik hubungan antara $d$ dan $r$ dan daerah scalling region menunjukkan nilai dimensi fraktal. 


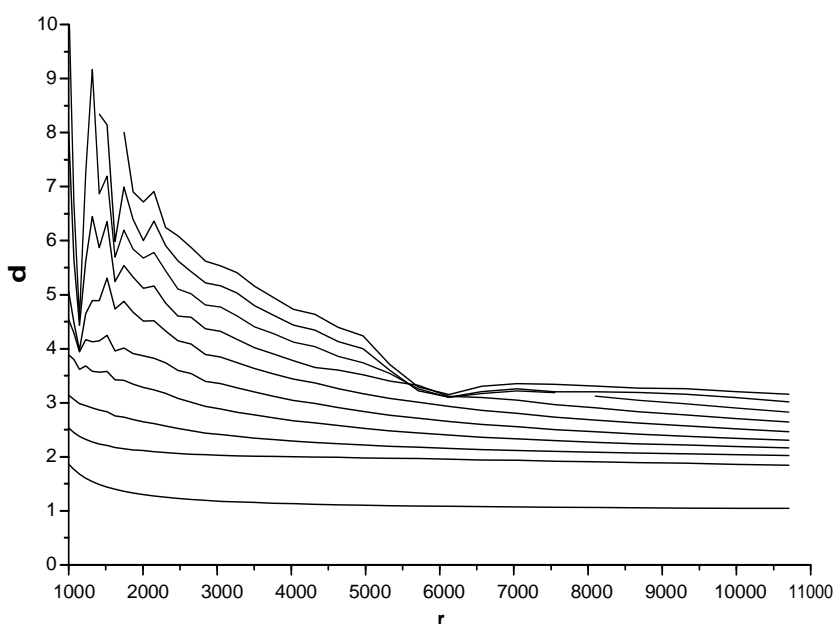

Gambar 6. Grafik hubungan dimensi korelasi dan $r$ tremor vulkanik menunjukan scalling region di sekitar $r=5500-6500$ dan $d=3,14$.

\section{ESTIMASI LYAPUNOV EXPONENT}

Lyapunov exponent mendeskripsikan ukuran penyebaran dari titik titik terdekat dalam diagram attraktor. Metode untuk menghitung nilai Lyapunov exponent dari data runtun waktu diajukan oleh [11]. Asumsikan titik $\boldsymbol{x}_{\boldsymbol{n}}$ berada dalam diagram attraktor yang

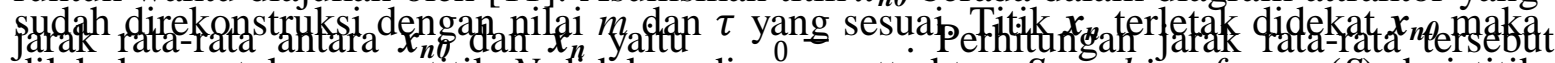
dilakukan untuk semua titik $N$ didalam diagram attraktor. Stretching factor $(S)$ dari titik titik dalam diagram attraktor dituliskan dalam persamaan berikut;

$$
=\frac{1}{0} \quad 0^{-} \quad \text { ) }
$$

Dimana $\quad 0$ merupakan jumlah titik disekitar 0

$[7]$.

Grafik hubungan antara nilai $S$ dan jumlah titik dalam diagram attraktor $N$ memperlihatkan nilai $S$ bertambah besar seiring dengan semakin banyak jumlah titik yang melingkupi diagram attraktor seperti Gambar 7. Metode least-square diterapkan untuk membentuk garis lurus dari grafik hubungan antara nilai $S$ dan $N$. Slope dari garis lurus tersebut ditentukan sebagai nilai Lyapunov exponent.

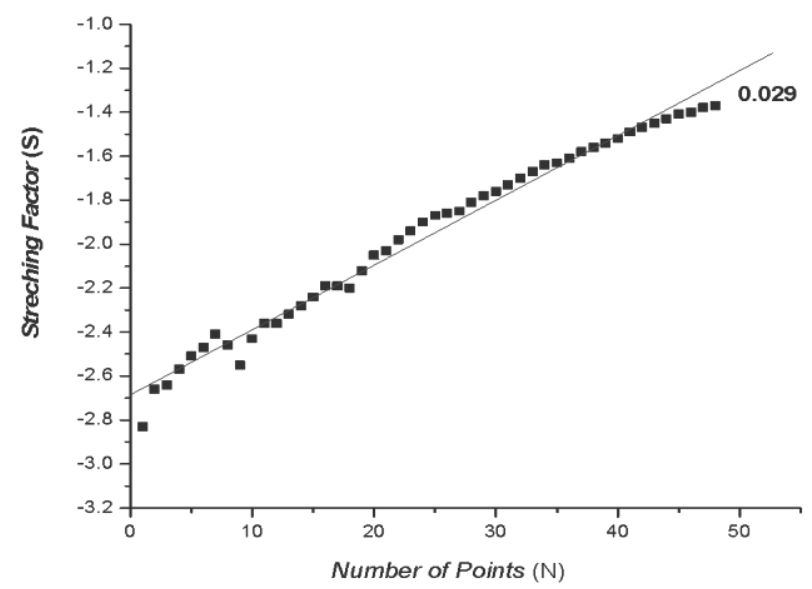

Gambar 7. Estimasi nilai Lyapunov exponent tremor vulkanik gunung Raung. 


\section{HASIL DAN PEMBAHASAN}

Perubahan dinamika titik-titik dalam diagram attraktor menggambarkan variasi parameter fisis yang mengendalikan sistem non linier tersebut. Perubahan secara temporal dinamika titik-titik dalam diagram attraktor dapat dilihat dari perubahan nilai Lyapunov exponent dan dimensi fraktalnya. Pada penelitian ini perubahan secara temporal dimensi fraktal tremor vulkanik gunung Raung dapat dilihat pada Gambar 8. Dimensi fraktal tremor vulkanik gunung Raung berada dalam range yang tetap selama bulan OktoberNovember 2012 yaitu berkisar pada range 2,91-3,35.

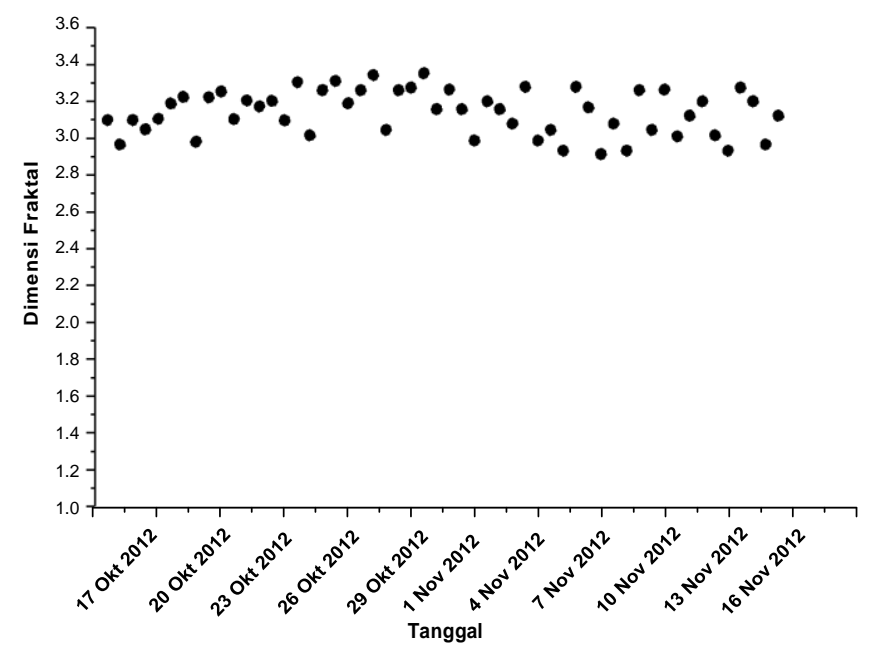

Gambar 8. Sebaran dimensi fraktal tremor vulkanik gunung Raung selama bulan Oktober-November 2012.

Perubahan secara temporal dari nilai Lyapunov exponent juga memperlihatkan kondisi yang sama seperti perubahan secara temporal dari dimensi fraktal dan frekuensi, dimana nilai Lyapunov exponent tremor vulkanik gunung Raung berkisar pada rentan 0,016-0,030 seperti terlihat pada Gambar 9 .

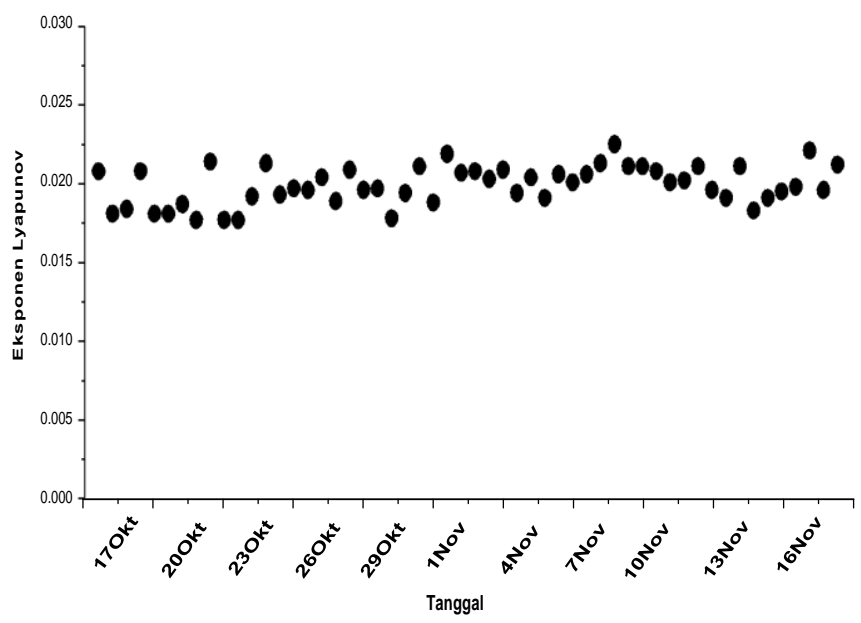

Gambar 9. Sebaran nilai Lyapunov exponent tremor vulkanik gunung Raung selama bulan Oktober-November 2012. 
Beberapa penelitian mengenai analisis non linier yang sudah dilakukan di beberapa gunungapi dapat dilihat pada Tabel 2 antara lain analisis tremor vulkanik yang terekam di gunung Etna [12], tremor vulkanik yang terekam di gunung Vatnajokull [13], tremor harmonik ynag terekam di gunung Semeru [10] dan tremor vulkanik yang terekam di gunung Sakurajima [14]. Dari semua hasil penelitian tersebut didapatkan nilai dimensi fraktal yang rendah untuk tremor vulkanik.

Tabel 2. Dimensi Fraktal beberapa gunungapi

$\begin{array}{|cc|}\text { Gunungapi } & \text { Dimensi Fraktal } \\ \text { Kilauea } & 3,1-4,1 \\ \text { Etna } & 1,6 \\ \text { Vatnajokull } & 2,83-2,92 \\ \text { Sangay } & 2,4-3,5 \\ \text { Semeru } & 1,6-1,9 \\ \text { Sakurajima } & 1,8-2,3\end{array}$

Sinyal kaotik memiliki karakteristik nilai Lyapunov exponent positif dan nilai dimensi fraktal yang rendah pada diagram attraktornya. Karakteristik ini didapatkan pada hasil analisis non linier yang telah dilakukan pada data tremor vulkanik gunung Raung. Berdasarkan hasil analisis non linier, tremor vulkanik gunung Raung memiliki nilai dimensi fraktal yaitu 2,91-3,35 dan nilai Lyapunov exponent yaitu 0,016 - 0,030.

Interpretasi mengenai sumber tremor vulkanik menjadi sangat penting untuk dibahas. Studi dan analisis non linier untuk model magmatik tremor vulkanik akibat aliran magma dalam saluran berbentuk dyke telah dilakukan oleh Julian [2], dari model yang dibuat menunjukkan bahwa variasi tekanan memberikan bentuk model tremor vulkanik dengan bentuk harmonik, subharmonik dan kaotik. Keadaan ini terlihat dari bentuk attraktor dan bentuk spektrumnya. Pada tahun 1997, Nurcahya melengkapi studi analisis non linier untuk model magmatik dalam saluran berbentuk silinder dan dari model yang dibuat dinyatakan bahwa perubahan parameter fisika yang statik (viskositas magma, panjang dan diameter saluran) ataupun parameter fisika yang dinamik (beda tekanan pada ujung-ujung saluran) akan menjadikan adanya tremor vulkanik yang harmonik, harmonik ganda dan kaotik.

Berdasarkan hasil analisis non linier yang telah dilakukan serta berdasarkan kenyataan secara visual yang nampak bahwa kubah lava gunung Raung berbentuk lingkaran seperti terlihat pada Gambar 10 maka model yang digunakan untuk menginterpretasikan sumber tremor vulkanik gunung Raung yaitu model magmatik dalam saluran berbentuk silinder yang dibuat oleh Nurcahya (1997). Berdasarkan pemodelan tersebut maka dapat diyatakan bahwa sumber dari tremor vulkanik gunung Raung disebabkan oleh aliran magma didalam pipa konduit berbentuk silinder. Berdasarkan 
bentuk attraktor dan nilai dimensi fraktalnya, aliran magma yang menjadi sumber tremor vulkanik gunung Raung diakibatkan oleh tekanan yang tidak konstan tetapi tekanan yang sifatnya random.

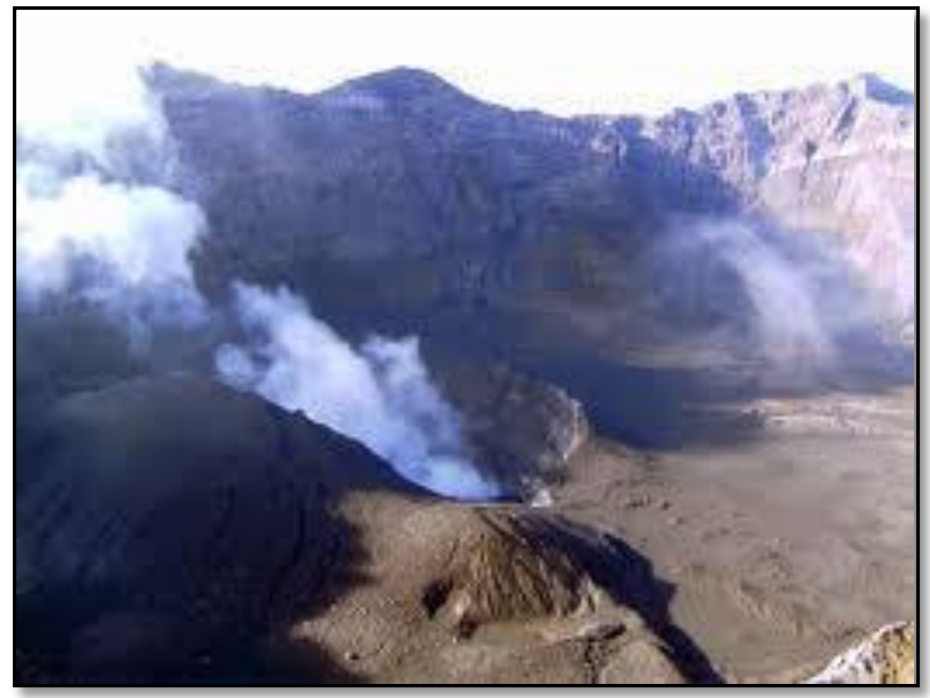

Gambar 10. Kenampakan visual puncak gunung Raung pada tanggal 11 Maret 2012 (Dokumentasi PPGA Raung).

Apabila dilihat dari grafik kegempaan gunung Raung tahun 2011-2013 yang memperlihatkan pada tahun 2011 aktifitas kegempaan gunung Raung didominasi oleh gempa vulkanik dangkal kemudian aktifitas gempa vulkanik dangkal mulai menurun pada bulan April tahun 2012 dan diikuti meningkatnya gempa tektonik jauh. Munculnya gempa tektonik menjadi pemicu adanya gempa vulkanik di gunung Raung. Aliran magma menuju permukaan sepanjang pipa konduit menjadi sumber tremor vulkanik gunung Raung. Aliran magma tersebut diakibatkan oleh tekanan yang tidak konstan. Aktifitas visual saat kejadian tremor vulkanik gunung Raung memperlihatkan kepulan asap di puncak gunung Raung dengan tinggi mencapai 70 meter seperti terlihat pada Gambar 11.

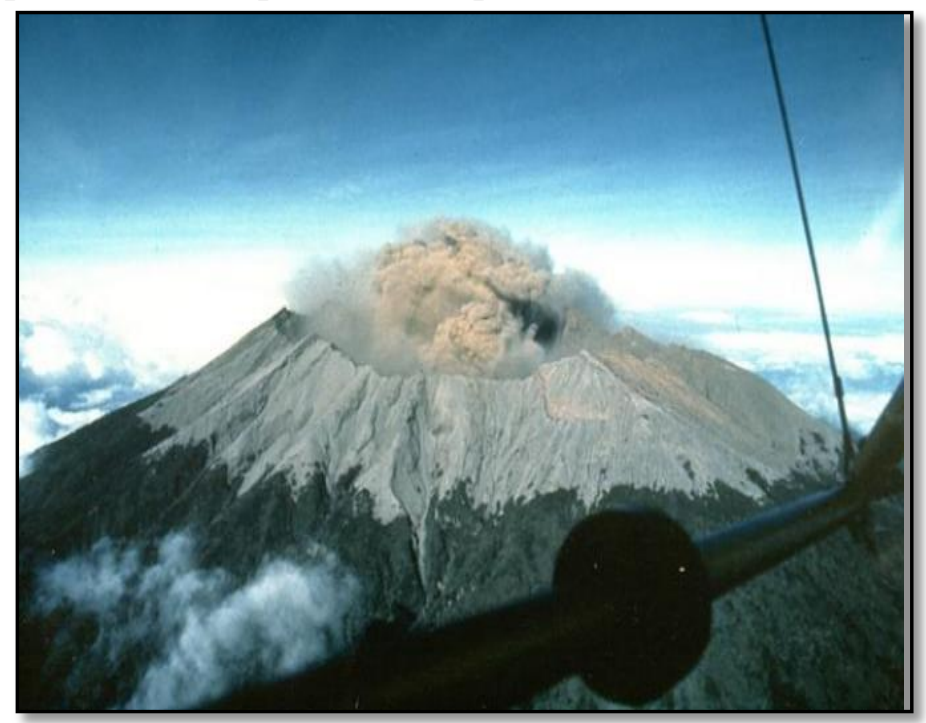

Gambar 11. Kepulan asap dengan tinggi mencapai 70 meter terlihat di puncak gunung Raung pada tanggal 22 November 2012 (Dokumentasi PPGA Raung). 


\section{KESIMPULAN}

Kesimpulan yang didapatkan dari penelitian ini yaitu dimensi fraktal diagram attraktor tremor vulkanik gunungapi Raung mempunyai nilai yang rendah yaitu berkisar pada rentan 2,91- 3,35 dan Nilai Lyapunov exponent tremor vulkanik gunungapi Raung mempunyai nilai positif yaitu berkisar pada rentan 0,016 - 0,030 dan berdasarkan nilai dimensi fraktal dan Lyapunov exponent maka dapat dinyatakan bahwa tremor vulkanik gunungapi Raung bersifat kaotik.

\section{DAFTAR PUSTAKA}

[1] Suparman, D., Wahyudi., Isya, N.D,. 1984, Pemetaan Geologi Gunungapi Raung, Jawa Timur, PVMBG. Bandung.

[2] Julian, R. B., 1994. Volcanic Tremor: Nonlinier Exicitation by Fluid Flow, Journal of Geophysical Research, 99(B6): 11859-11877.

[3] Minakami, T., 1974. Seismology of Volcanoes in Japan, Physical Volcanology, Elsevier Scientific Publishing Company, Amsterdam. NewYork.

[4] Schlindwein, V., Wassermann, J., Scherbaum, F., 1995. Spectral Analysis of Harmonic Tremor Signals at Mt. Semeru Volcano, Indonesia, Geophysical Research Letter. 22:1685-1688.

[5] Nurcahya, B.E., 1997. Dinamika Kaotik Tremor Vulkanik akibat Aliran Magma didalam Saluran Berbenntuk Silinder Model Teoritis dengan Studi Kasus pada Gunung Semeru, Merapi dan Krakatau, Tesis, Universitas Gadjah Mada, Yogyakarta.

[6] Shick, R., 1988. Volcanic Tremor-Source Mechanism and Correlation with Eruptive Natural, Journal of Geophysical Research. 7: 125-244.

[7] Konstantinou, K.I., Lin, C.H., 2004. Nonlinear Time Series Analysis of Volcanic Tremor Events Recorded at Sangay Volcano, Ecuador, Pure appl Geophysic. $161: 145163$.

[8] Maryanto, S., Mulyana, I., 2009. Temporal Change of Fractal Dimension of Explosion Earthquakes and Harmonic Tremors at Semeru Volcano, East Java, Indonesia, using Critical Exponent Method, World Academy of Science and Technology, 18.

[9] Goltz, C., 1997. Fractal and Chaotic Properties of Earthquakes, Springer-Verlag Berlin Heidelberg. New York. p. 12-15.

[10] Maryanto, S., Santosa, D.R., Mulyana, I., Hendrasto, M., 2011. Fractal and Chaos of Explosion Earthquakes Followed by Harmonic Tremor at Semeru Volcano, East Java, Indonesia. International Journal of Scientific and Engineering Research, 2: 2229-5518.

[11] Roseistein, M.T., Collins, J.J., and Deluca, C.J. 1993. A Practical Method for the Calculating Largest Lyapunov Exponents from Small Datasets, Physica D 65, 117134.

[12] Godano, C., Carcadi, C., and Privitera, E. 1996. Intermittent Behaviour of Volcanic Tremor at Mt. Etna, Pure Appl. Geophys. 147:729-744. 
[13] Konstantinou, K. I., 2002. Deterministic Nonlinear Source Processes of Volcanic Tremor Signals Accompanying the 1996 Vatnajokull Eruption, Central Iceland, Geophys. J. Int. 148: 663-675.

[14] Maryanto, S., Iguchi, M., Tameguri, T., 2011. Fractal Analyses of Harmonic at Sakurajima Volcano, Japan, International Conference on Chemical and Enviromental Science. 